\section{Questión}

Periodismo / Comunicación ISSN 1669-6581
- Av. $44 \mathrm{~N}^{\circ} 676,1^{\circ}$ piso

CP 1900 - La Plata - Argentina

(4) www.perio.unlp.edu.ar/question

Con sentido en el tiempo

Sol Moreyra

DOI: https://doi.org/10.24215/16696581e341

Con sentido en el tiempo

\title{
Sense in time
}

Sol Moreyra / msolmoreyra@gmail.com https://madriguerafotografia.blogspot.com/

Es tiempo de estar unidos pero distanciados.

Es tiempo de guardarnos.

No será nada fácil, pero es necesario.

Es necesario ciertos cambios de hábitos, pero sobre todo de actitud.

Debemos practicar la empatía, el compañerismo, el pensar en el otro, convencernos que sólo así podremos salir adelante. Ese es el significado del éxito hoy. Quizás el que tuvimos que tener siempre.

Todo un planeta ante el mismo desafío, dejemos los egoísmos y las ideologías de lado, escuchemos a los que saben, respetemos los protocolos de cuidado, unamos nuestras energías y tiremos la soga para el mismo lado.

Seamos el adulto responsable de nuestros hijos, padres, abuelos, amigos, compañeros y vecinos.

Porque sólo siendo responsables, solidarios, conscientes y activos vamos a poder ganar ésta batalla.

Quizás hoy vemos el futuro de color gris y cada vez más oscuro, pero lo importante es intentar con nuestros sueños, que no se vuelva negro. 
Dejemos de preguntarnos qué tan lejos estamos de estar cerca y pensemos en darle espacio al tiempo, que la verdadera libertad es la que tenemos en nuestro interior.

Dejemos el miedo de lado, para poder activar nuestra imaginación para seguir amando sin besos ni abrazos.

El mundo después de esto seguirá girando, pero no volverá a ser el mismo... ¿y vos? 